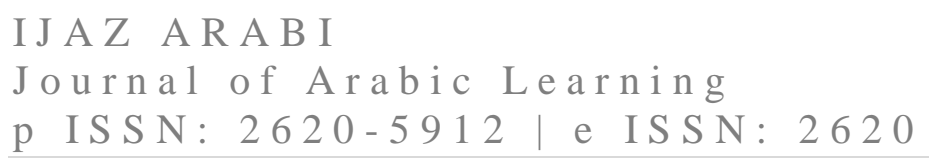

\title{
ARABIC TEACHERS' COMPETENCE: A CASE OF MADRASAH SCHOOLS IN MALUKU
}

\author{
Ummu Saidah, Saidna Zulfiqar Bin-Tahir, Nuril Mufidah \\ IAIN Ambon, Universitas Iqra Buru Maluku, UIN Maulana Malik Ibrahim Malang \\ ummusaidaharief@gmail.com, saidnazulfiqar@gmail.com,nurilmufidah86@uin- \\ malang.ac.id
}

\begin{abstract}
:
In reality, not a few teachers who have been certified as educators are less competent in teaching the field of study. Many teachers are also able to master the subject matter, but they have difficult to present the material. This research applied a qualitative method using a case study design. It was carried out in the State Madrasah schools of Salahutu District, Central Maluku Regency. This research was conducted from August to 02 November 2017. The subjects of this study were 3 Arabic teachers, two principals and 6 class students totaling 12 informants. Based on the results, it was found that the pedagogic competence of Arabic language teachers was still relatively low due to the several indicators that were not implemented during the learning process. The personality's competence of Arabic language teachers is relatively good compared to their pedagogical competence. The lacks of training, facilities, and rewards have caused the low educational competence of teachers. Their personal competence is due to strict supervision and their commitment to building the ummah as followers of religion and not because of their profession as teachers. Students are motivated to learn Arabic due to the motivation is given by the teacher, the mu'amalah is good between teachers and students, and there is a continuous and rigorous evaluation.
\end{abstract}

Keywords: Arabic teacher, competence, madrasah schools

\section{INTRODUCTION}

The teacher as one of the elements of managing education in an educational institution that is directly involved in the learning process, he must be able to maintain his class, formulate learning objectives operationally, determine learning material, establish methods that are appropriate to the learning objectives, evaluate learning outcomes and other professional abilities so that the learning process teaching can run according to the goals to be achieved (Bin-Tahir \& Rinantanti, 2016; Rinantanti et al, 2017). The teacher is also the spearhead in the learning process. Therefore, there is no doubt that the competency role of a teacher is crucial to the success of the implementation of educational programs, and it is mostly determined by the function and pedagogic competence of the teacher (bin Tahir, 2008). This competence is undoubted must be owned by a teacher whose application is directly related to students and will have an impact on student achievement.

Vol. 1 No. 2 / October 2018

IJAZ ARABI homepage: http://ejournal.uin-malang.ac.id/index.php/ijazarabi 
In the Republic of Indonesia Law, Number 20 of 2003 concerning the national education system, what is meant by education is a conscious and planned effort to create a learning atmosphere and learning process so that students actively develop their potential to have spiritual strength, control themselves, society, nation, and state (Sudjana, 2010). Teacher competency is a combination of personal, scientific, technological, social, and spiritual abilities that form a competence standard of the teacher's profession, which includes mastery of the material, understanding of students, educating learning, personal development and professionalism. In the national policy perspective, the government has formulated four types of teacher competencies, as stated in the explanation of government regulation No. 19 of 2005 concerning national education standards, namely pedagogic, personality, social, and professional competencies (Musfah, 2011).

Teacher pedagogic competence is one of the determinants of the success of learning for students in a particular subject or field of study. Pedagogic competence is defined as the ability of teachers in the learning management of students including the understanding of students, designing and implementing learning, evaluating learning outcomes, and developing students to actualize the variety of potential they have (Mulyasa, 2009). Personality competencies must support pedagogic competence because personality competence has a direct and cumulative influence on students' behavior (Hamalik, 2000). Influenced behaviors include study habits, discipline, learning desire, and learning motivation (Bin-Tahir et al., 2018). What is meant by personality here provides knowledge, skills, and attitudes? The character displayed by the teacher in learning will always be seen, observed, and assessed by students.

Thus the teacher of one element in learning has a multi-role not only limited as a "teacher" who conducts the transfer of knowledge, but also as a mentor who encourages potential, develops alternatives, and mobilizes students in learning (Mufidah \& BinTahir, 2018). That is, the teacher has complex tasks and responsibilities towards the achievement of educational goals, where teachers are not only required to master the knowledge that will be taught and have a set of knowledge and technical teaching skills but also required to display a personality that can be a role model for students.

In reality, not a few teachers who have been certified educators are less competent in teaching the field of study they receive. Many teachers are also able to master the subject matter, but it is difficult to present the material. In addition, guidance, and training for teachers that are inadequate and equitable. This fact is no longer a secret anymore in educational institutions, especially in madrasah schools. This does not mean that the teacher does not have professionalism, but is doubtful about the pedagogic competence in the field of study that he has. Moreover, this deviation usually occurs in schools in remote areas that lack teachers. The lack of a teacher's pedagogic competency will undoubtedly have an impact on student learning achievement (Anwar et al., 2007).

Based on the Teacher Competency Test Results (UKG) conducted in 2013, Maluku Province is ranked 32nd out of 34 provinces, or only two levels from North Maluku Province in the position of caretaker. The low UKG results correlate with teacher 
qualifications in Maluku, most of who have not fulfilled the minimum requirements for a bachelor's degree. Of the 29,466 teachers in Maluku (kindergarten, elementary, junior high, high school/vocational high school) with S1 qualifications as many as 10,181 people, while the S2 was only 116 people, the rest were high school and D2 graduates, and D3. Even teachers with high school education still have around 7,291 people. The districts that contributed to the data of high school teachers were Central Maluku (Malteng) totaling 1,830 people, West Southeast Maluku (MTB) 1,315, and West Seram (SBB) 664 people. The conditions that occur in public schools in Maluku Province are very alarming, especially in madrasah schools (Ibtidaiyah, Tsanawiyah, and Aliyah) which must be the concern of all parties, especially by the local government (LPMP Maluku, 2013).

Based on the results of the consolidation of the preparation of the National Examination (UN) for the Madrasah Aliyah School in Ambon which was followed up with the 2nd Try Out with the Online System, the results of the scores reached 80 percent of the completeness level. The achievement of these results, by itself, shows the readiness of MAN students in Ambon in the face of the implementation of the 2015/2016 academic year, UN has been declared as ready. In the first try out, the results have not been satisfactory, namely only reaching 30 to 40 percent of graduation rates, to boost students to get maximum results. Although the national examination results data for the last three years in several fields of study, especially in Arabic subject shows good results, in reality, students have not mastered Arabic following the competence at the level of the madrasah schools (Kemenag, 2016).

The low level of education in Maluku Province is inseparable from the low competency of teachers based on teacher competency test data that contribute to low student achievement and low mastery of Arabic students in madrasah schools in Maluku. Based on the identification of the above problems, this research deserves further investigation.

\section{METHOD}

The design used in this study is a case study, which is an intensive study of an individual or a social unit in depth where researchers try to find all the essential variables in the development of the subject. It requires detailed studies in collecting data about the subject at the moment, its experience, environment, and how these factors relate to each other (Donald et al., 2007). According to Sugiyono (2012), the qualitative research is often called a naturalistic method because the investigation is carried out in natural settings, also called ethnographic methods, because at first this method was used more for research in cultural anthropology, also called qualitative methods because of the collection and the analysis is more qualitative, the object of the study is very natural with the data that develops as it is, not manipulated by the researcher and the presence of the researcher does not really affect the dynamics of the object.

Vol. 1 No. 2 / October 2018

IJAZ ARABI homepage: http://ejournal.uin-malang.ac.id/index.php/ijazarabi 
Subjects are the primary source of data (primary) research, which has data about the variables studied. The subjects in this study were all Arabic teachers in Madrasah schools in Salahutu District, Central Maluku District, which numbered 3 Madrasas. In each school there is one teacher, so the number of research subjects is 4 Arabic teachers. The secondary data sources are obtained from the environment where the subject is located at the school. This data was obtained through interviews with principals, teachers, and students, as well as through learning documents. Determination of informants in this study through census sampling or also called saturated sampling and total sampling, meaning that all subjects in the study made as research informants is due to the amount that exists and meets the standards and criteria as informants (Sugiyono, 2013).

Data collection techniques are ways that are done to obtain data contained in research subjects. To collect accurate data, researchers used several methods, including:

1) Observation, namely data collection techniques carried out through systematic observation and recording of the phenomenon under study. Implementation of observations in this study in a semi-participant manner means the researchers involved in some activities and is passive in some events. Observations in this study also use semistructured observation, that is, there has been a part of the observation guide, and some will be observed at the location. This method is to obtain data on the pedagogic competence of Arabic teachers in Madrasas.

2) Interviews are tools to gather information by asking questions orally to obtain oral answers as well. This type of interview in this study is also free to be guided, meaning that this interview uses a semi-structured question frame, but does not rule out the possibility of new questions relating to research problems. This method is to obtain data about teacher competencies and factors that strengthen or weaken the pedagogical competence of Arabic teachers and to find out students' learning motivation that is collected and analyzed descriptively.

3) Documentation is a way to obtain data sourced from written data, such as laws and regulations, syllabus and Lesson Plan, student report cards, etc. as supporting data for teacher competencies.

There are three stages in analyzing data in this study which include (Kothari, 2004): 1) Data Reduction; at this stage, collect all the data obtained, both from primary sources, namely interviews, observations, and documentation, as well as data obtained from secondary sources, namely library data taken from educational books that explain the teacher's pedagogical competence. 2) Data Verification; at this stage, the researchers choose and sort, select and classify the data that has been collected from the implementation of the research to verify which data is by the problem and which is not. 3) Draw conclusions; after the data collected is selected and grouped, then interpreted by researchers based on data and theory and then provides conclusions based on the need to answer the problems in the study.

\section{RESULTS}

Vol. 1 No. 2 / October 2018

IJAZ ARABI homepage: http://ejournal.uin-malang.ac.id/index.php/ijazarabi 
From the results of research observations conducted on August 30, 2016, on the teaching and learning process held by the Arabic teachers in the classroom, it can be described the pedagogical and personal competencies of the MTSN and MAN 2 Tulehu of Arabic language teachers' competencies as a following:

a. Arabic Teacher of MTSN Tulehu

Table 1: Arabic Teacher's Competence (Teacher A)

\begin{tabular}{clccc}
\hline No & \multicolumn{1}{c}{ Pedagogical Competence } & Always & Sometimes & Never \\
\hline 1 & Understanding of education & $\sqrt{ }$ & - & - \\
& insight/foundation & & & \\
2 & Understanding the students' background & $\sqrt{ }$ & - & - \\
3 & Curriculum and syllabus development & - & - & $\sqrt{ }$ \\
4 & Learning design & - & - & $\sqrt{ }$ \\
5 & Carry out learning & $\sqrt{ }$ & - & - \\
6 & Utilization of learning technology & - & $\sqrt{ }$ & - \\
7 & Evaluate learning outcomes & - & $\sqrt{ }$ & - \\
8 & Development of students to actualize & - & $\sqrt{ }$ & - \\
& various potentials & & & \\
\hline No & Personal Competence & Always & Sometimes & Never \\
\hline 1 & Good personality & $\sqrt{ }$ & - & - \\
2 & Responsibility & $\sqrt{ }$ & - & - \\
3 & Openness & - & $\sqrt{ }$ & - \\
4 & Discipline & $\sqrt{ }$ & - & - \\
5 & Good character as a role model & $\sqrt{ }$ & - & - \\
6 & Want to learn and move on & $\sqrt{ }$ & - & - \\
\hline
\end{tabular}

The symbol $(\sqrt{ })$ in Table 1 indicates the treatment and symbol (-) indicates the absence of treatment by the teacher in the teaching and learning process. The table above shows that the pedagogic competence of Arabic teachers has not run optimally, although, in the first indicator (Understanding of insight/educational foundation), the second indicator (Understanding of students) and the fifth indicator (Implementing learning) has been well implemented, but Other indicators have not been implemented well, namely the third indicator (curriculum development/syllabus), the fourth (learning development and planning), and the sixth indicator (the use of media and technology in learning).

Table 1 also points out that the Arabic teacher's personal competence in the Tulehu State Madrasah Tsanawiyah is very high due to all the indicators of personal competence of a teacher already possessed by an Arabic teacher at MTSN Tulehu. Although the 3rd indicator (openness) has not been maximally applied by the teacher, the indicator does not prevent the teacher from communicating, getting to know the students, and establishing good relations between teacher-students. From the description above, it can be concluded that the competence of the Tulehu MTSN Arabic teacher is good 
enough or can be classified in the medium category, even though the pedagogic competence has not been maximally applied by the teacher, but the lack of competence can be balanced with the advantages of the teacher's personal competence so that learning not monotonous and boring for students.

b. Arabic Teacher of MAN 2 Tulehu

Table 2: Arabic Teacher's Competence (Teacher B)

\begin{tabular}{clccc}
\hline No & \multicolumn{1}{c}{ Pedagogical Competence } & Always & Sometimes & Never \\
\hline 1 & Understanding of education & - & - & $\sqrt{ }$ \\
& insight/foundation & & & \\
2 & Understanding the students' background & - & $\sqrt{ }$ & - \\
3 & Curriculum and syllabus development & - & - & $\sqrt{ }$ \\
4 & Learning design & - & - & $\sqrt{ }$ \\
5 & Carry out learning & $\sqrt{ }$ & - & - \\
6 & Utilization of learning technology & - & - & $\sqrt{ }$ \\
7 & Evaluate learning outcomes & - & $\sqrt{ }$ & - \\
8 & Development of students to actualize & - & $\sqrt{ }$ & - \\
& various potentials & & & \\
\hline No & Personal Competence & Always & Sometimes & Never \\
\hline 1 & Good personality & $\sqrt{ }$ & - & - \\
2 & Responsibility & $\sqrt{ }$ & - & - \\
3 & Openness & - & $\sqrt{ }$ & - \\
4 & Discipline & $\sqrt{ }$ & - & - \\
5 & Good character as a role model & $\sqrt{ }$ & - & - \\
6 & Want to learn and move on & - & $\sqrt{ }$ & - \\
\hline
\end{tabular}

Table 2 above shows that the pedagogical competence of Arabic language teachers of MAN 2 Tulehu is at a moderate level because some indicators of pedagogical competence are not implemented correctly, including the indicators 1, 3, 4 and 6. While the personal competence of teacher B can be classified as good. The impact of the lack of teacher competency resulted in the learning process of Arabic appearing to be monotonous, unattractive, unpleasant and boring for students so that students were not active to attend Arabic learning and to accept what the teacher gave material.

c. Arabic Teacher of MAN 2 Tulehu

Table 3: Arabic Teacher's Competence (Teacher C)

\begin{tabular}{clccc}
\hline No & \multicolumn{1}{c}{ Pedagogical Competence } & Always & Sometimes & Never \\
\hline 1 & Understanding of education & - & $\sqrt{ }$ & - \\
& insight/foundation & & & \\
2 & Understanding the students' background & - & $\sqrt{ }$ & - \\
3 & Curriculum and syllabus development & - & - & $\sqrt{ }$ \\
\hline
\end{tabular}

Vol. 1 No. 2 / October 2018

IJAZ ARABI homepage: http://ejournal.uin-malang.ac.id/index.php/ijazarabi 


\begin{tabular}{llccc}
\hline 4 & Learning design & - & $\sqrt{ }$ & - \\
5 & Carry out learning & $\sqrt{ }$ & - & - \\
6 & Utilization of learning technology & - & $\sqrt{ }$ & - \\
7 & Evaluate learning outcomes & - & $\sqrt{ }$ & - \\
8 & Development of students to actualize & - & $\sqrt{ }$ & - \\
& various potentials & & & \\
\hline No & Personal Competence & Always & Sometimes & Never \\
\hline 1 & Good personality & $\sqrt{ }$ & - & - \\
2 & Responsibility & $\sqrt{ }$ & - & - \\
3 & Openness & - & $\sqrt{ }$ & - \\
4 & Discipline & $\sqrt{ }$ & - & - \\
5 & Good character as a role model & $\sqrt{ }$ & - & - \\
6 & Want to learn and move on & $\sqrt{ }$ & - & - \\
\hline
\end{tabular}

Table 3 above describes the pedagogical competence of Arabic $\mathrm{C}$ teacher in the medium or good category where the teacher understands concepts and theories about language teaching; sometimes he plans to learn at each meeting and sometimes also uses the media in his teaching. Likewise, the personality competencies have belonged to the good category so that learning is not monotonous, interesting and not boring for students in learning. From the data above, the researchers concluded that the pedagogic competence of Arabic language teachers in Salahutu District was still relatively low compared to their relatively good personal competence.

\section{DISCUSSION}

The results of the study found that the pedagogical competence of Arabic teachers in Salahutu District, Central Maluku had not run optimally, several indicators were not implemented at the time of learning such as the use of media, preparation of lesson plan and syllabus, the development of teaching materials and the use of learning technology. It is due to the absence of training provided to teachers, the absence of supporting facilities and also the absence of rewards from schools and related agencies for outstanding teachers. This is by Harun's statement (2010) that said that pedagogic competence would be successful if teachers were given continuous training following the demands of the times and also rewards for outstanding teachers.

The lack of pedagogic competence of these teachers can be understood as the position of Maluku as a key interpreter of the results of the Teacher Competency Test (UKG). However, the lack of pedagogic competence is not a threat to the failure of learning, because this lack of competence can be embellished by the high personal competence of teachers in creating harmony, directed, continuous, enjoyable and more flexible learning process.

Their educational background and experience cause the teacher's personal competence during the language learning from an early age in which they try to apply to 
students according to their expertise. It is in Hamalik's opinion (2012) which states that the lesson will be meaningful for students if the teacher tries to relate it to past experiences, or experiences that have been previously owned. Meanwhile, according to Usman (2001), stating that explanation is one of the most critical aspects of the teacher's activities in his interaction with students in the classroom, and usually, the teacher dominates the conversation and has a direct influence, for example in giving facts, ideas, or opinions. Therefore, its effectiveness must be addressed to achieve optimal results from the explanation and discussion so that it is meaningful to students.

The description above explains that learning requires direct interaction between students and the teacher who will strengthen the relationship between one another to be ready to give and receive knowledge. Teaching delivered by teachers should have a variety of methods that can arouse enthusiasm and motivate students in the teaching and learning process to take place in a classroom where a teacher can achieve it through the personal competence that he has through his own learning experience.

The results of the study prove that the lack of training, facilities, and rewards have resulted in the low pedagogical competence of teachers. Whereas their personal competence remains good due to the background and experience of the teacher, the existence of strict supervision and their commitment in building the ummah as followers of religion and not because of their profession as teachers.

It is in line with Hamalik's opinion (2012), stating that learning is a structured combination that includes human elements, materials, facilities, equipment, and procedures that influence each other to achieve learning goals. Based on the statement above, a teacher's educational competence must be supported by adequate equipment, learning materials, and also learning facilities. It is what influences the low pedagogic capability of Arabic teachers in Saluhutu District. However, along with Hamalik's statement above, the ability of teachers to understand students in depth and the implementation of learning includes an understanding of student developmental psychology, social environment and the ability of parents is a cycle of knowledge that teachers have understood through their personal potential to overcome deficiencies pedagogic competence in the teaching and learning process.

The findings of the study show that students are motivated to learn Arabic due to the motivation is given by the teacher, mu'amalah is good between teachers and students, and there is a continuous and rigorous evaluation. These three things are dominant in motivating students to learn Arabic. This motive cannot be observed directly but can be interpreted in the behavior of the learners, in the form of stimuli, encouragement, or power generation the emergence of specific action. But the emotional approach of the teacher has caused students to feel safe (danger-free), love needs, needs are respected and respected and needs self-actualization.

Self-actualization, respect or respect, a sense of belonging, and a sense of love or affection, a sense of security, and security are fundamental physiological needs. These needs are according to Maslow in Uno (2009) who can motivate individual behavior. 
Therefore, what a person sees and feels will undoubtedly arouse his request as far as what he sees has a relationship with his interests in managing the teacher as a role model to follow to succeed and achieve the learning objectives.

The success of learning can be seen from the quality of the teaching and learning process in the classroom, which will directly demonstrate the mastery of learning management by the teacher, thus explaining the learning achievement achieved by students. This is important, especially in the context of teacher professionalism. Therefore, to expedite the learning process, it is necessary to pay attention to the management of learning, both those found in the teacher, students and those outside themselves. The teaching and learning process is the core of the overall education process with teachers as the primary role holders and role models for students (Engkoswara \& Komariah, 2011).

The teaching and learning process is a process that contains a series of actions and teachers by reciprocal relationships that take place in an educational situation to achieve specific goals. Interaction or reciprocal relationship between teacher and student is the primary requirement for the teaching and learning process. Learning interactions and events have a broader meaning, not just the relationship between the teacher and students in the classroom, but in the form of educative communication that can lead to a feeling of comfort, protection, respect, and attention, and naturally, these motives will motivate students to learn while increasing their learning outcomes.

From the above discussion, the researcher can conclude the relationship between qualitative phenomena examined in a cycle of Arabic teacher competency in Saluhutu Sub-district as follows:

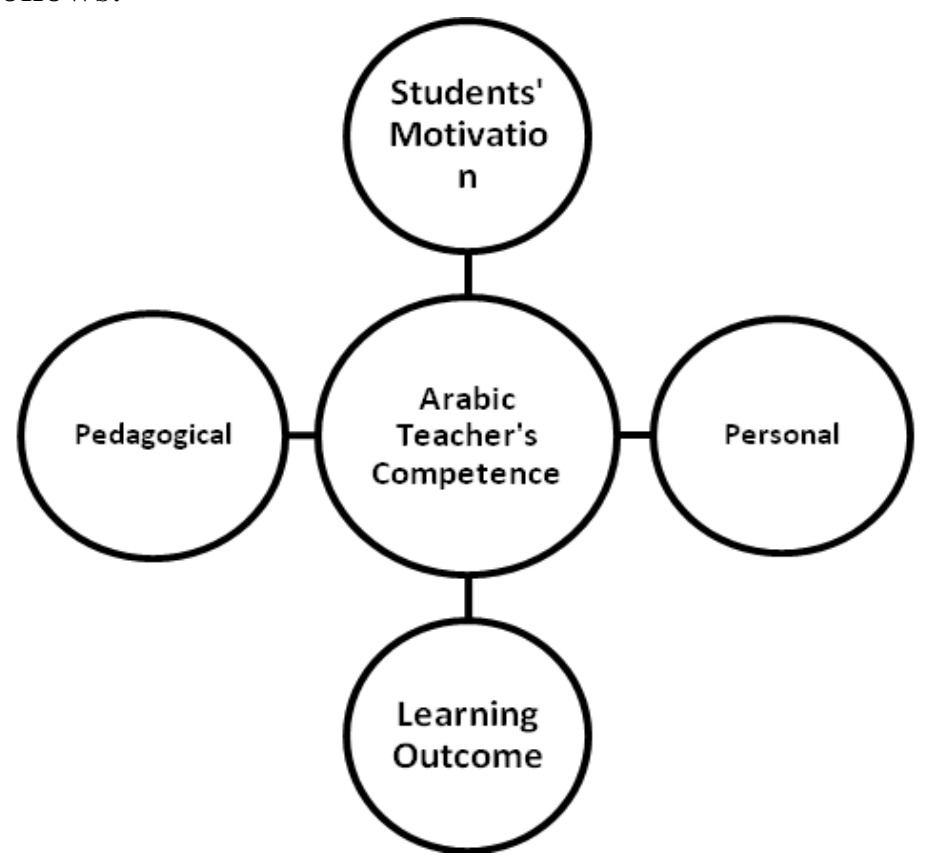

Figure 1: Component of Arabic Teacher's Competences 
The components above show that despite the lack of competence of Arabic teachers on pedagogical aspects, the deficiencies can be embellished by their personal competence which can partially motivate students in learning and holistically as a whole can improve their learning outcomes. In other words, if the teacher's personal competence is good, then the lack of pedagogic competence will be balanced and by itself will motivate and improve student learning outcomes.

\section{CONCLUSION}

Based on the results and discussion of this study, researchers can conclude the following conclusions:

a. Pedagogical competence of Arabic language teachers throughout Salahutu District is still low because several indicators are not implemented during learning.

b. Personal competence of Arabic language teachers in Salahutu Sub-district is considered good compared to their pedagogical competence.

c. Lack of training, facilities, and rewards have resulted in the low pedagogical competence of teachers. While their personal competence is due to teacher experience, strict supervision and their commitment to building the ummah as followers of religion and not because of their profession as teachers.

d. Students are motivated to learn Arabic because the teacher gives the motivation, mu'amalah is good between teachers and students, and there is a continuous and rigorous evaluation.

Based on this type of research that is qualitative, it certainly has several shortcomings that cannot be generalized to other situations and cases so that the researcher will give some suggestions. The suggestions that can be submitted regarding the findings and discussion in this study are as follows:

a. For the government or related agencies, efforts should be made to continuously improve teacher competencies through various programs to enhance the quality of education, such as workshop activities, improvement of education levels, and efforts to strengthen competence but wellprogrammed supervision is needed.

b. School and related service managers should facilitate teachers to attend and conduct instructional system design training in improving their pedagogical competence and understanding of learning planning and management activities.

c. In the aspect of reward, the school principal should be able to act decisively in taking a policy on the discipline and achievement of teachers and other matters relating to the teaching and learning process that must balance reward and punishment.

d. For the following researchers to study more about the social and professional competence of teachers and develop a relationship between the competence of Arabic teachers towards student learning achievement by using quantitative path analysis and SEM. 


\section{REFERENCES}

Anwar, S, dkk. (2007). Kompetensi Guru Madrasah, Balai Penelitian dan Pengembangan Agama, Jakarta.

Akhyak, Mohamad Idrus, Yunus Abu Bakar. (2013). Implementation of Teachers Pedagogy Competence to Optimizing Learners Development in Public Primary School in Indonesia. International Journal of Education and Research. Vol. 1 No. 9 September 2013.

Bin Tahir, S. Z. (2008). Cara Praktis Belajar Bahasa Arab: At-Taysiir Fii at-Ta'liim AlLugha al-Arabiyah (Vol. 2). Jakarta: Media Pustaka Qalam.

Bin Tahir, S.Z and Yulini Rinantanti. (2015). Multilingual Lecturers' Competence in English Teaching at the University of Iqra Buru, Indonesia. Asian EFL Journal, Vol 86.

Bin-Tahir, S. Z., Atmowardoyo, H., Dollah, S., Rinantanti, Y., \& Suriaman, A. (2018). Multilingual And Mono-Multilingual Students' Performance in English Speaking. Journal of Advanced English Studies, 1(2), 32-38.

Cohen, L, Manion, L, Morrison, K., (2005). Research Method in Education. $5^{\text {th }}$ Edition. London: Routledge.

Departemen Agama RI, (2004). Standar Kompetensi Guru Pendidikan Agama Islam Pada Sekolah Umum dan Madrasah (Jakarta: Depag RI Direktorat Jenderal Kelembagaan Agama Islam).

Donald, A, Jacobs, C, Razavieh, A., (2007). PengantarPenelitianDalamPendidikan, Cet III. Yogyakarta: Pustaka pelajar.

Engkoswara dan Aan Komariah. (2011). Administrasi Pendidikan. Bandung: Alfabeta.

Fadlilah, Asep Muhammad Irfan, (2014). KompetensiPedagogik Dan Profesionalisme Guru Bahasa Arab Se-Kota Bandung. S2 thesis dipublikasikan, UniversitasPendidikan Indonesia, 2014Diaksespada 23 Maret 2016 darihttp://repository.upi.edu/12841/.

Hamalik, O., (2012). Kurikulumdan Pembelajaran. Jakarta: Bumi Aksara.

Harun, C. Z., (2012). Manajemen Sumber Daya Pendidikan. Yogyakarta: Pena Persada.

Jubaidah, Kompetensi Guru Bahasa Arab. (2015). Studi Arab: Jurnal Pendidikan Bahasa Arab. Volume 6, Nomor 2,p. 20.

Kemenag, (2016). Pemantapan Persiapan Ujian Nasional (UN) MAN di Ambon. Online. $\begin{array}{lllll}\text { Diakses } & \text { pada } & \text { tanggal } & 25 & \text { Maret }\end{array}$ darihttp://maluku.kemenag.go.id/index.php?a=berita\&id=344800. 2016.

Kothari, C.R. (2004). Research Methodology, Method and Technique, Second revised edition.New Delhi; New Age International (P) Ltd., Publishers. 2004.

LPMP Provinsi Maluku, (2013). Hasil uji kompetensi guru (UKG). Online. Diaksespada 22 Maret 2016 darihttp://tabloidjubi.com/2015/11/20/hasil-ukg-2015-malukuposisi-juru-kunci-dari-34-provinsi/. 
Miles, M. B. and Huberman, A. M., (1994). Qualitative Data Analysis: An Expanded Sourcebook. London: Sage.

Mufidah, N., \& Bin-Tahir, S. Z. (2018). Arabic Acquisition through Facebook Group Learning. Ijaz Arabi Journal of Arabic Learning, 1(1).

Mulyasa, E., (2009). Standar Kompetensi dan Sertifikasi Guru. Bandung: RemajaRosdakarya.

Peraturan Pemerintah Nomor 74 tahun 2008 tentang Guru dan Dosen, Bandung: Citra Umbara, 2009.

Rinantanti, Y., Rahman, M. A., Atmowardoyo, H., \& Bin-Tahir, S. Z. (2017). Perception of Senior High School EFL Teachers in Papua, Indonesia towards Their Own Competence. Journal of Language Teaching and Research, 8(6), 1181-1189.

Sudjana, N., (2011). Dasar-Dasar Proses Belajar Mengajar. Bandung: Sinar Baru Algesindo.

Sugiyono. (2012). Metode Penelitian Pendidikan: Pendekatan Kuantitatif, Kualitatif, dan $R \& D$. Bandung: Alfabeta.

Sugiyono. (2013). Metode Penelitian Kualitatif, Kuantitatif, dan Metode Kombinasi (Cet I, Yogyakarta: Alfabeta.

Timoshtchenko and Ludmila Bavrina. (2009). Realization of Prof essional Pedagogical Competence Delivering ICT-Based Courses. European Integration studies. 2009. No 3.

Uno, H. B., (2009). Profesi Keguruan, Problema, Solusi, dan Reformasi Pendidikan di Indonesia. Jakarta: Bumi Aksara.

Usman M.Uzer, (2001). Menjadi Guru Profesional, Bandung: PT. Remaja Rosda Karya. 